NORDISK MUSEOLOGI $1996 \cdot 1$, S. $101-108$

\title{
RÄTTEN TILL EN ALLDELES EGEN RAM
}

\section{Clara Ảhlvik}

Arbetsstyrkan samlad. Hundratals arbetare vid Jönköpings Tändsticksfabrik har blivit ombedda att samlas vid fabrikens virkeslager, klättra upp på högarna av travade aspstockar for att bli fotograferade. Längst fram sitter pojkarna, därefter kommer de flesta av de vuxna männen och högst upp, balanserande på de obarkade stockarna, stär flickorna och kvinnorna.

Ann Jonsson på Tändsticksmuseet i Jönköping visade mig det här fotografiet när vi skulle påbörja arbetet med att bygga om museets basutställningar 1993. Och
Arbetsstyrkan samlad. Fotot är taget omkring 1895 , då tändsticksfabriken var som störst, vad gäller arbetsstyrka och fabriksomrade. Fotograf A. Jonason, Kongl.

Hoffotograf. Tillhör Jönköpings Tändsticksmuseum.

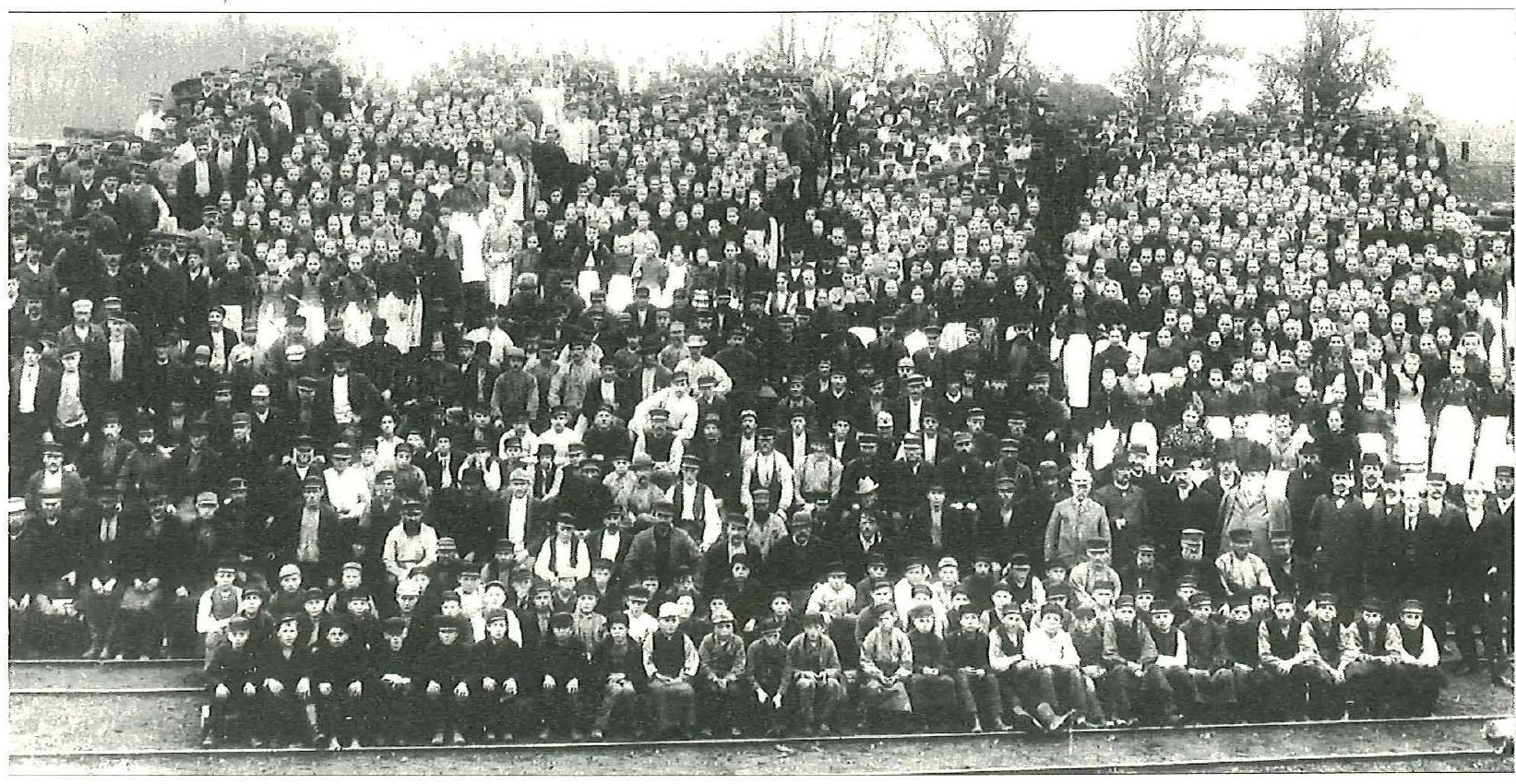


Clara $\AA$ HLVIK

102 bilden av alla dessa namnlösa barn bet sig fast på näthinnan. Ansikte vid ansikte, små som knappnålshuvuden, knappt skönjbara. Inga namn, ingen historia. Bara dessa anonyma ansikten. I museets samlingar fanns stora porträttavlor med tunga guldramar. Men alla dessa barn? Var fanns de? Och varför berördes jag så starkt av detta fotografi? Varför blev det så viktigt att ta fasta på den känslan? Hur ville jag gestalta detta i utställningen? Vad ville jag, vad ville barnen?

\section{BARNEN PA TÄNDSTICKSFABRIKEN}

Det är de småväxta fabriksflickorna jag tydligast ser framför mig där de som en svärm nattflyn skynda till eller från arbetet. En hårt tillknuten schalett om huvudet, en tunn schal, knuten om livet eller en kofta, en sladdrig kjol, bleka av sysslandet med svavel och fosfor i ohälsosamma lokaler, oftast tandlösa - så ser jag dem. (Sigrid Lugner, Minnen fri̊n 1860talets Jönköping.)

Barnen på tändsticksfabriken arbetade under mycket svåra förhållanden. Arbetsmiljön var direkt livsfarlig, framförallt under andra hälften av 1800-talet, då fabriken tillverkade fosfortändstickor. Stickans tändsats innehöll den giftiga gula fosforn, som var orsaken till sjukdomen fosfornekros, eller käkbrand som den också kallades. Fosforn åt sig in i tänderna, luckrade upp käkbenet och ledde i många fall till döden.

I läkarjournalen finner vi följande beskrivning av sjukdomen:

Gossen Carl P., f. 1841 intogs å

Kliniska Institutets kirurgiska afdelning d. 24 dec. 1854 .

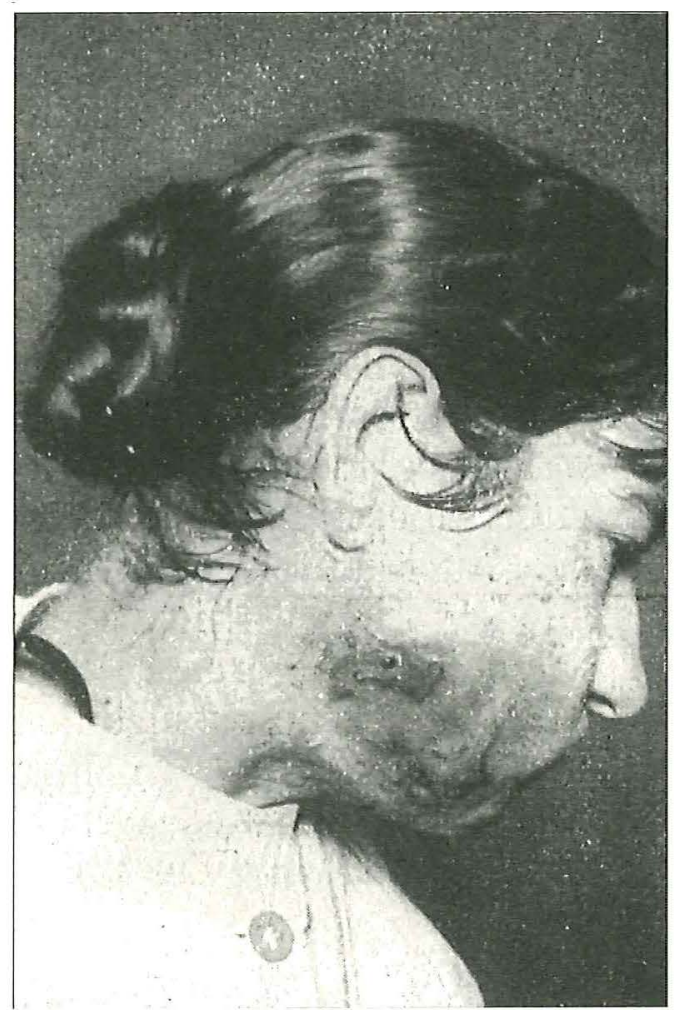

En ung kvinna som drabbats av sjukdomen fosfornekros. Bilden är hämtad ur Lehrbuch der Chirurgie, Jena 1915.

STATUS PRAESENS: blek ansigtsfärg, kinderna plussiga, den venstra oedematöst uppdrifven. Vid inre vinkeln af venstra ögat en fistelöppning, hvarifrån ett gröngult stinkande var uttömmer sig. En införd sond stöter i temligen stort omfång på karierande ben. Vid inre vinkeln af högra ögat en annan dylik abcess, som ännu ej öppnat sig. De två främsta oxeltänderna på venstra sidan af öfverkäken utfallne: hörntanden på samma sida och alla framtänderna lösa, långt framskjutande emedan tandköttet dragit sig undan. Detta var missfärgadt och innehöll en mängd små öppningar, varigenom ett kopiöst, stinkande var utrann. Käkbenet kändes vid sondering öfverallt skrofligt. 
Carl dog den 25 mars 1855, 14 år gammal.

Till en början förstod man inte, att det var fosforn som orsakade sjukdomen. Och eftersom sjukdomen började i tänderna, trodde man att det berodde på att arbetarna hade dåliga tänder. Först 1879 började man läkarundersöka arbetarna på fabriken. Samtliga kvinnor under 20 år var tvungna att dra ut sina dåliga tänder för att få fortsätta sitt arbete. De fick göra en veckas uppehåll $\mathrm{i}$ arbetet, utan ersättning från sjukkassan. Sjukdomen försvann, när tillverkningen av fosfortändstickor förbjöds i Sverige 1920.

Barnen på tändsticksfabriken hade samma arbetsuppgifter som de vuxna, men fick bara en tredjedel i lön. De arbetade tio timmar om dagen, sex dagar i veckan. År 1860 utgjorde barnen mer än hälften av arbetsstyrkan. De lågavlönade barnen var eftertraktade och fabriken annonserade ofta efter barnarbetare:

Tändsticksfabrikens Annonser. Platser finnas wid Tändstickstillverkningen för 50 à 60 gossar eller flickor öfwer 12 år, sökande böra skynda att anmäla sig. (Jönköpings Tidning år 1859)

Vi vet mycket lite om hur barnen såg på sin tid som barnarbetare vid fabriken. I boken Barnarbetare och arbetarbarn, utgiven av Nordiska museet, finns utdrag från uppteckningar, där man berättar om tiden som barnarbetare inom andra näringar. Minnena präglas av hunger, trötthet, tårar, blodiga händer, bitterhet. Jönköpings Läns museum har gjort några uppteckningar efter tändsticksarbetare och när dessa personer berättar om sin tid som barnarbetare väljer de att lyfta fram de ljusare sidorna:
Man tog inte hänsyn till minderåriga på den tiden. En torkinrättning för råstickor som sköttes av fyra gubbar, hann inte med tillverkningen utan körde övertid till kl 10 på kvällarna. Gubbarna byttes vid så att två gick hem varannan kväll kl 6. Och så fick schåarebasen skicka dit av sitt folk som ersättare i fyra timmar. Jag blev en ersättare varannan kväll för en betalning av 68 öre för kvällen. Övertidsersättning förekom inte. Men jag gick gärna, kände mig vuxen och fullgod /.../ Jag var fjorton och ett halvt år och inte bortskämd. (Man, född 1886)

Jag började arbeta 1910, 13 år gammal /.../ Till julen hade jag sparat ihop 12:50. För det köpte jag två kandelabrar i nickel. Jag tror att de kostade 3:styck. Sedan snickrade jag två stycken piedestaler $1.10 \mathrm{~m}$ höga, att ställa ljusstakarna på. Det var julklapp till mina föräldrar. Det var en underbar upplevelse att ha gjort något själv och kunna köpa något för pengar som man själv tjänat. (Man, född 1897)

Arbetet skänkte erkänsla.

I Tändsticksmuseets utställningar och i bildspel berättar vi om gossen Carl, som drabbades av fosfornekros, om arbetsförhållandena, om arbetsuppgifterna. Men en plats i utställningen tänkte vi viga endast åt barnen. Och hur skulle vi skildra barnen på tändsticksfabriken?

\section{PORTRÄTTGALLERIET}

Som utställningsproducent har jag stor makt. Det är jag som väljer och vrakar bland mängden av fakta, föremål, fotografier. Det är jag som väljer uttryck, betydelse, tyngd kontra lätthet. Vad vill jag bära fram, vad vill jag belysa, vad vill jag? Min lojalitet bor främst hos mig själv och hos de människor vars historia jag väljer att 


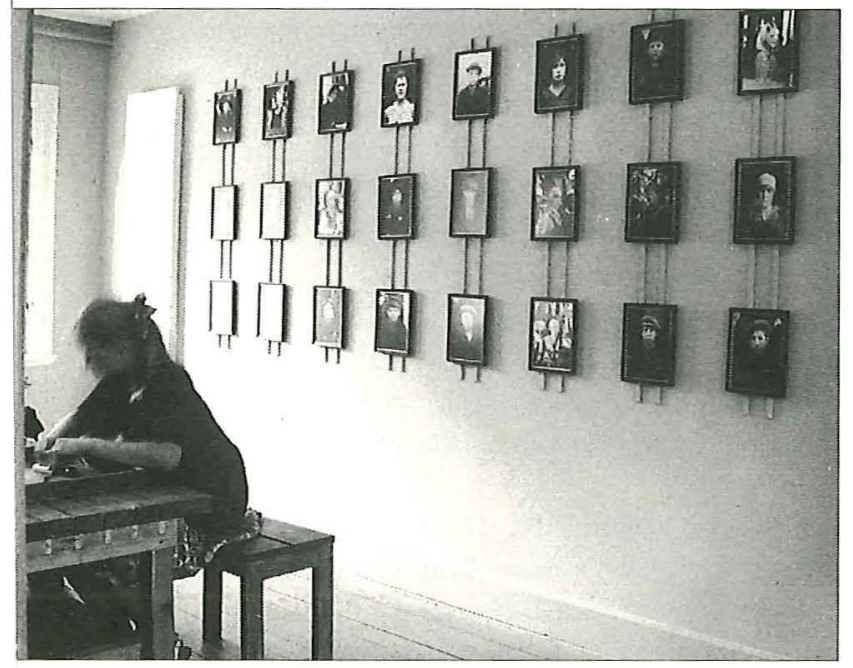

Porträttgalleriet $i$ Tändsticksmuseets basutställning. Det genialt enkla och vackra galleriet är formgivet av Mikael Andersson, Arkitekturkompaniet AB. Foto Clara Ablvik.

lyfta fram. Kan vi - jag och de - finna en gemensam nämnare, ett gemensamt uttryck?

Det finns många sätt att skildra barnen från tändsticksfabriken. Men det kändes särskilt viktigt att ta hänsyn till barnens egen värdighet, deras egen självbild. Speciellt med tanke på att jag ville belysa individen, barnet. Lyfta ut dem ur den anonyma tillvaro som de fått $\mathrm{i}$ tändsticksfabrikens arkiv.

Gruppfotografiet bildade utgångspunkt och jag valde att hämta fram 24 barn, tolv flickor och tolv pojkar ur fotografiet och ge dem varsin ram. Det visade sig att flickornas ansikten var så otydliga att vi fick ta flickor från andra fotografier. Tillsammans kom de utvalda barnen att bilda ett porträttgalleri i museet.

Det var ett enkelt och självklart val att

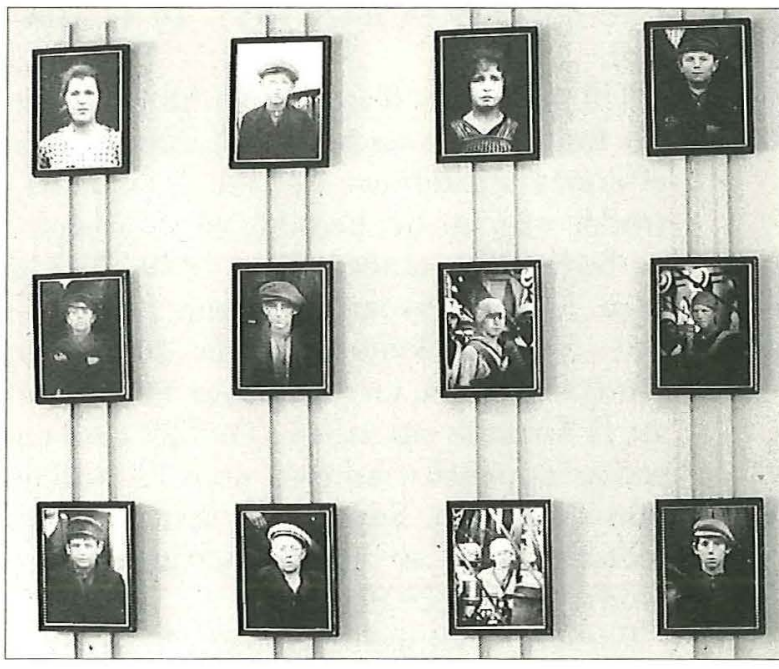

låta rama in barnen, en och en. Och jag har förstått varför det var så lätt.

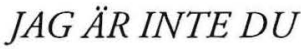

Jag är yngst i en syskonskara om fyra flickor: Britta, Anna, Kerstin och Clara. Pappa civilingenjör, mamma lärare. Vi bodde $\mathrm{i}$ en villa $\mathrm{i}$ Täby. En vanlig medelklassfamilj i ett vanligt medelklassområde. Jag var ett sladdbarn, en till i raden av flickor. Att vara en i syskonskaran, minst och alltid $\mathrm{i}$ vägen, är ett starkt minne från min uppväxt. Så många andra hade alltid företräde.

Strax innan jag skulle fylla tre år gick familjen till ateljéfotografen. Vi hade fått nya klänningar, sydda av farmor. Det var de vackraste av klänningar, med spets i kjolen och i ryggen knäpptes de av små slipade glasknappar, precis som riktiga diamanter. De var i olika ljusa pastellfärger, en var ljusgul, en ljusgrön, en ljusblå och en rosa. Vi skulle vara tärnor på ett bröllop, nästan som riktiga prinsessor. Allt 
Systrarna Britta, Anna, Kerstin och Clara, varen 1964.

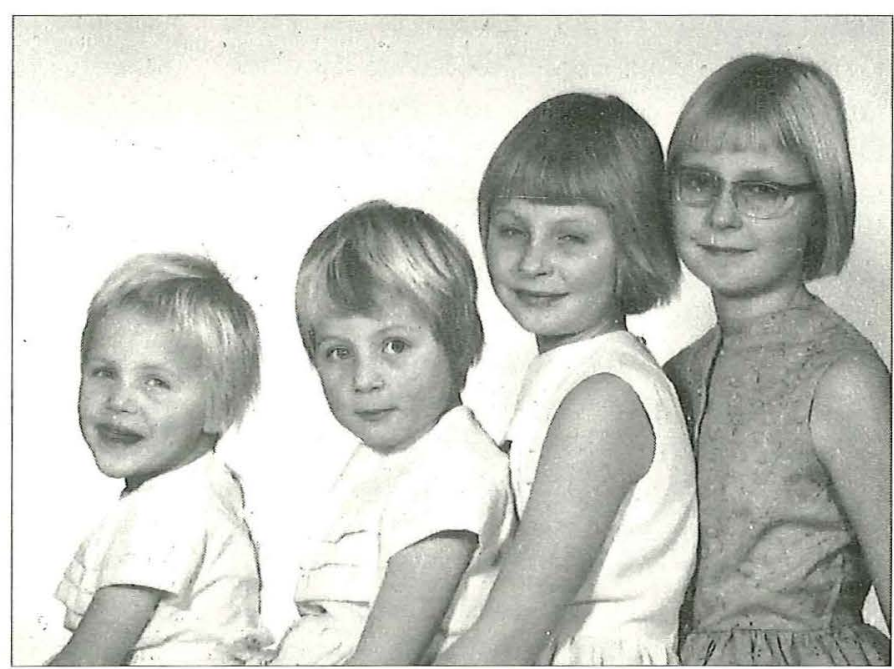

var så otroligt spännande och jag var mycket lycklig. Men jag antogs vara för liten för att få följa med på bröllopet. Jag var hos min lekkamrat Ann, som bodde tvärs över gatan, när jag märkte att de hade åkt. Utan mig. Jag trodde att de hade glömt mig.

Detta var den enda gången jag gick till fotografen som barn. Några år senare skilde sig mina föräldrar. Alla fotografier från tiden före skilsmässan försvann ner i lådor i förråd och källare. Det var som om våra liv började om. All tid dessförinnan var förbjuden tid. Och senare upptäckte jag till min förvåning att andra hade porträtt på sig själva som barn, ibland flera stycken, upphängda i ramar på väggen. Alla utom jag.

Så i porträttgalleriet möttes vi. Barnen från tändsticksfabriken och jag. Du är inte jag. Jag är inte du. Men vi betyder något. Galleriet blev en enkel och värdig bekräftelse på att alla barn är viktiga och unika. Och för mig blev det en akt av försoning. Att fà bli delaktig i skapandet av detta lilla vackra och betydelsefulla galleri skänkte tröst men även ren och skär lycka.

\section{$K \ddot{A N N} D I G$ SJ $\ddot{L} L V$}

Min berättelse kan synas väl privat. Men det privata är alltid egendomligt allmängiltigt. De känslor som finns inom mig finns även hos alla andra. Hur många av oss har inte mer eller mindre smärtsamt fått erfara att vi inte står i världens/föräldrarnas centrum? Men ju mer jag lär mig om mig själv och min egen historia, desto tydligare kan jag också skilja mellan mig själv och andra. Jag vet då, vad som är jag och vad som är de/det andra. Vet man inte det lägger man gärna över sina egna känslor på andra och låter dem agera ut ens känslor. Detta kallas projicering.

Om man synar museilandskapet med dessa ögon, möts man av ett kaotiskt virrvarr av projiceringar och det blir lätt att ironisera. Där finns fadersuppror, moderslängtan, konflikträdsla, oändliga trygghetsbehov, längtan bort, längtan till, eller 
Clara $\AA$ HLVIK

106 bara längtan (mina favoriter är Den Kämpande Arbetaren, Den Goda Bondefamiljen Som Leker Mamma Pappa Barn, Den Lyckliga Fiskaren/Hantverkaren/ Samen/Med Flera, Den Dumma Industrialismen och inte att förglömma Naturen Som Det Alltid Är Synd Om).

Så det besökaren möter i utställningarna speglar alltför ofta utställningsproducentens omedvetna, inre värld, fylld av önskningar, rädslor, behov och drömmar, och inte det som utställningen faktiskt utger sig för att skildra. Ett sätt att söka undvika projiceringar, som ligger i dagens trend, är att skapa rent estetiska, föremålsrika utställningar. Tyvärr tenderar dessa utställningar att ge väldigt lite, både av kunskap och känslor.

En strikt objektiv utställning är knap-

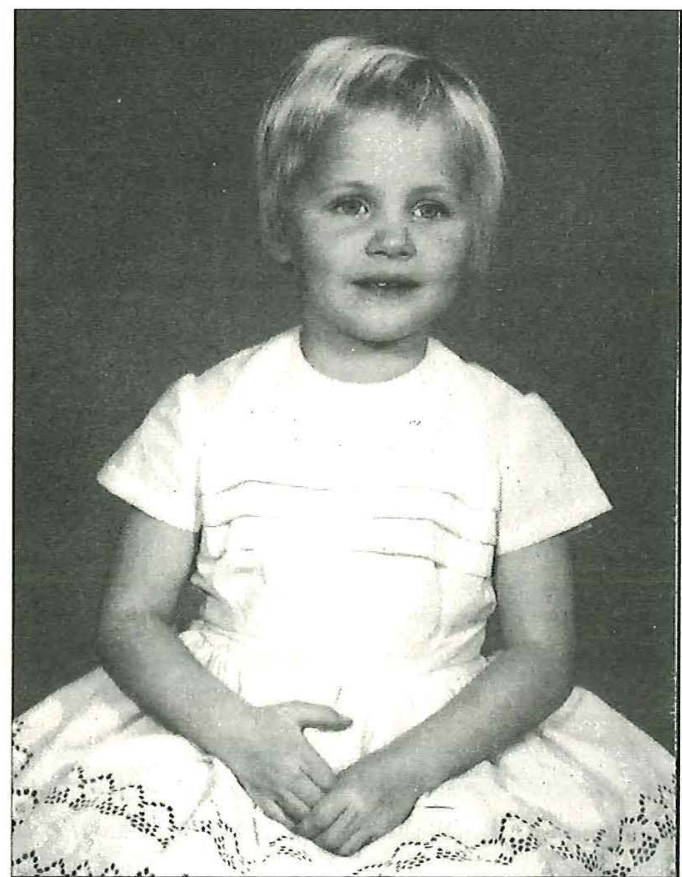

past lösningen. Jag, som utställningsproducent, bör ta fasta på det som berör mig och utveckla det i utställningen. Samtidigt har besökaren rätt att få ta del av den kunskap som finns, fà veta mer om det vi faktiskt tror oss veta. Ett tillvägagångssätt är att i utställningens avsnitt tydligt skilja mellan föremålens berättelse - tidens främsta vittnesbörd - och friare iscensättningar - teater, dramatik, poesi. För visst ska vi i utställningen ha friheten att dramatisera, levandegöra, leka, använda oss själva, vår erfarenhet och vår lust. Men besökaren har rätt att få möjligheten att själv ta ställning.

Det är i mellanrummet som bildas i det medvetna mötet mellan oss - jag och de/det - som möjligheterna finns. Där kan i bästa fall något spännande ske. I vil-

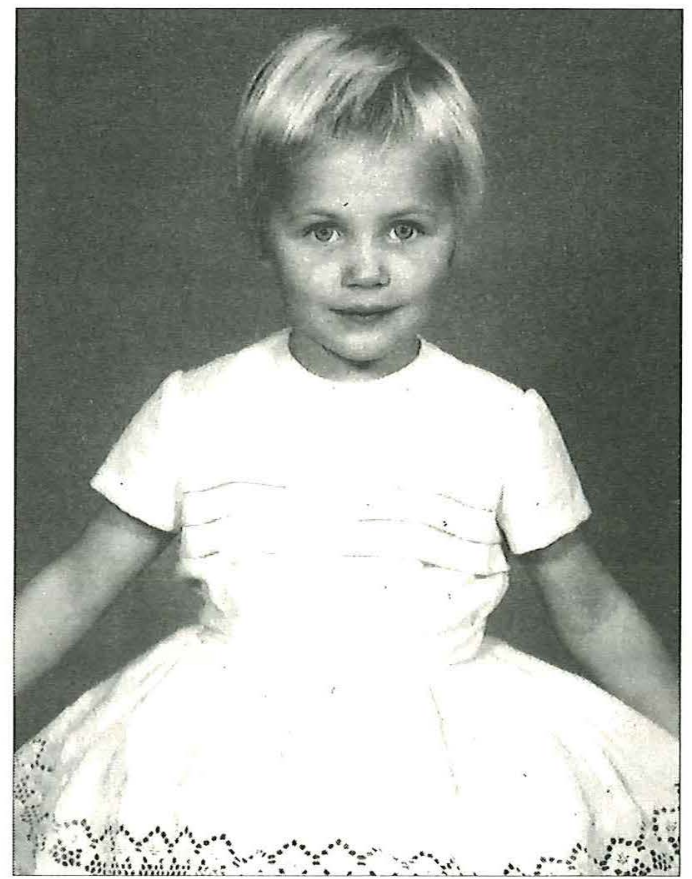


ket fall blir det ärligare, för då tvingas jag att möta de/det andra på deras villkor, så som det framstår. Nordiska museets motto - Känn dig själv - är angeläget och nödvändigt. Ity museer handskas med känslor, med liv, med dina och mina liv, såväl som med andras. Samlar små skärvor av liv.

PS

Under arbetet med denna artikel ringer min syster Kerstin. Vi pratar om fotografiet, om klänningarna. Det visar det sig att det finns tre fotografier av mig, alldeles ensam framför kameran, tagna vid samma tillfälle. Kerstin har varit och rotat i lådorna och hittat mängder av gamla fotografier, bland annat dessa tre. En liten och

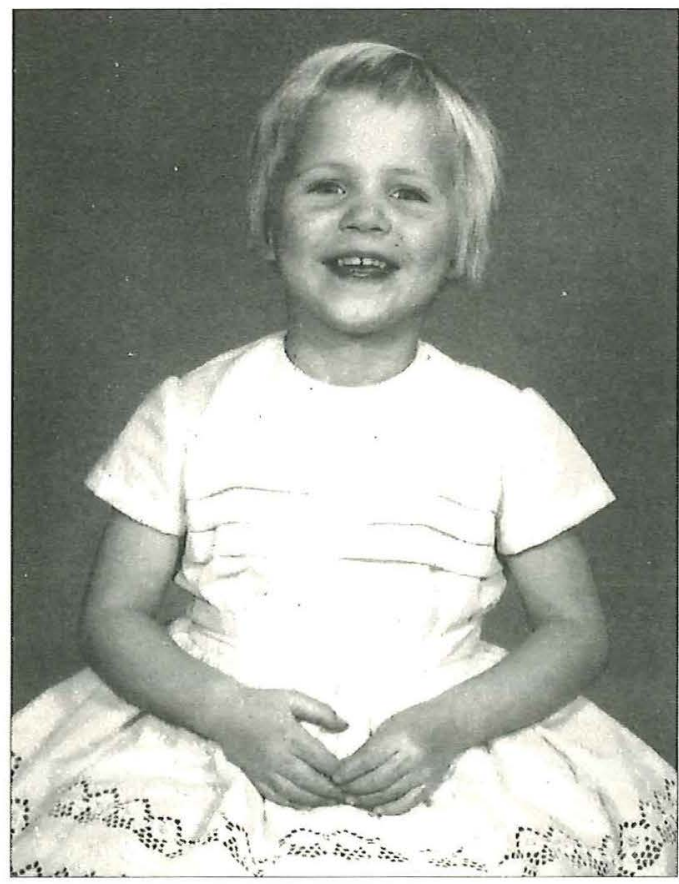

mycket stolt flicka i all sin glans. Med spets i kjolen och diamantknappar i ryggen...

\section{SUMMARY}

The right to a frame of one's own

After completing an exhibition about a match-producing factory in Jönköping and the working conditions there at the turn of the century the author reflects on the decisions an producer of exhibitions must take about what objects to select, what facts and circumstances to highlight. The producer has the power to create and present a picture of the past, which implies a somewhat terrifying responsibility. What the deeper motives lie behind the decisions? The visitors are often confronted with idealized personalities, families and social groups corresponding to current clichés and cherished dreams, more or less conscious in the producers' minds and normally left out when the planning process is accounted for. She was herself very preoccupied with all the anonymous children working in the factory whom she could only meet as names on pay-rolls and as indistinct faces on some rare photographs of the labour force of the factory. She insisted on giving them a particular presence in the exhibition by making individual enhancements of some of the children's faces and framing them separately in a small gallery. She asks herself why she insisted and finds the explanation in a childhood

"Tre ganger Clara»" 
Clara $\AA$ hlvik

108 experience. She is the youngest of four sisters and experienced the frustration of being left out or forgotten on many important occasions because, being the youngest, she felt that she was not seen and did not really count. Perhaps this has given her a special sensibility towards the situation of other children.

Clara Åhlvik är ekonombistoriker. Efter frilansverk-

sambet som utställningsproducent är hon numera utstälningschef vid Riksutställningar.

Adr: Riksutställningar, Box 4715,

S-11692 Stockholm. 